\title{
MINERALOGICAL AND CHEMICAL CHARACTERISTICS OF BLACK COATINGS IN POSTOJNA CAVE SYSTEM
}

\author{
MINERALOŠKE IN KEMIJSKE ZNAČILNOSTI ČRNIH PREVLEK \\ V POSTOJNSKEM JAMSKEM SISTEMU
}

\author{
Nina ZUPANČIČ ${ }^{1}$, Stanka ŠEBELA² \& Miloš MILER ${ }^{3}$
}

\begin{abstract}
UDC 551.442:549(497.471)

Nina Zupančič, Stanka Šebela \& Miloš Miler: Mineralogical and chemical characteristics of black coatings in Postojna cave system

Mineralogical and chemical analyses of black coatings from two sites in Postojna cave system were studied. Scattered samples were taken from the entrance parts of the cave and from Črna Jama. Thin sections, powder X-ray diffraction (XRD) technique and scanning electron microscope coupled with energy dispersive X-ray spectrometer (SEM/EDS) were used. Microscopic investigation of thin sections of black coloured material from both locations revealed that the main material is carbonate - calcite, with evenly dispersed prevailingly minute opaque black grains. The XRD analysis on samples from both locations confirmed just a presence of calcite with minor quartz and dolomite, excluding $\mathrm{Mn}$ and $\mathrm{Fe}$ oxides or apatite-group minerals as reason for black colouring. The SEM/EDS analysis of samples from the entrance parts of Postojna cave system was consistent with XRD analysis, which did not show any $\mathrm{Mn}$ oxides. The high content of $\mathrm{C}$ measured in the black coatings from the cave entrance parts indicates organic $\mathrm{C}$, which deposited on the cave walls at time of the petrol explosion during WW2. We can attribute black coatings from Črna Jama to one form of organic $\mathrm{C}$ as well, but it is certainly different from the one in the entrance parts of Postojna cave system. As in Črna Jama no other evidence indicates for old human inhabitation of the place: torches of first tourists are a more probable origin of charcoal. On both locations black coatings can be at least partly described by microclimate conditions at cave entrances, which caused the deposition of organic material of allogenic origin (for example soot due to the forest fires).
\end{abstract}

Keywords: black coatings, mineralogy, chemistry, Postojna cave system, Slovenia.
Izvleček

UDK 551.442:549(497.471)

Nina Zupančič, Stanka Šebela \& Miloš Miler: Mineraloške in kemijske značilnosti črnih prevlek $v$ Postojnskem jamskem sistemu

Črne prevleke iz dveh nahajališč v Postojnskem jamskem sistemu so bile mineraloško in kemijsko analizirane. Naključni vzorci so bili pobrani iz vhodnih delov jame in iz Črne jame. Vzorce smo analizirali v polarizirani presevni svetlobi, $\mathrm{z}$ rentgensko difrakcijsko metodo ter $\mathrm{z}$ vrstičnim elektronskim mikroskopom $\mathrm{z}$ energijsko disperzijskim spektrometrom rentgenskih žarkov (SEM/EDS). Mikroskopska preiskava zbruskov iz obeh lokacij je pokazala, da je glavna sestavina črnih prevlek karbonat - kalcit, s posameznimi večinoma zelo majhnimi neprozornimi črnimi zrni. Metoda rentgenske difrakcije iz obeh nahajališč je potrdila le prisotnost kalcita in $\mathrm{v}$ manjši meri kremena in dolomita, pri čemer je izločila prisotnost Mn in Fe oksidov ali apatitove skupine mineralov (gvano netopirjev) kot vzrok za črne prevleke. SEM/EDS analiza vzorcev iz vhodnih delov Postojnskega jamskega sistema je potrdila analizo rentgenske difrakcije, ki ni pokazala Mn oksidov. Visoka vsebnost $\mathrm{C}$, merjenega $\mathrm{v}$ crnih prevlekah iz vhodnih delov jame, potrjuje organski $\mathrm{C}$, ki se je odložil na jamske stene $\mathrm{v}$ obdobju eksplozije bencina med 2.svetovno vojno. Tudi črne prevleke iz Črne jame lahko pripišemo organskemu C, ki pa je zagotovo drugačen od tistega $\mathrm{v}$ vhodnih delih Postojnskega jamskega sistema. Ker iz Črne jame ni znanih dokazov o starih poselitvah, so bakle prvih turistov najverjetnejši vzrok za oglje. $\mathrm{Na}$ obeh lokacijah bi morda lahko črne prevleke vsaj deloma razlagali $\mathrm{z}$ mikroklimatskimi razmerami na vhodih $\mathrm{v}$ jamo, ki so povzročili odlaganje organskega materiala zunanjega izvora (npr. saje gozdnih požarov).

Ključne besede: črne prevleke, mineralogija, kemija, Postojnski jamski sistem, Slovenija.

\footnotetext{
${ }^{1}$ Naravoslovnotehniška fakulteta, Oddelek za geologijo, Aškerčeva 12, 1000 Ljubljana, Slovenia, e-mail: nina.zupancic@ntf.uni-lj.si ${ }^{2}$ Karst Research Institute ZRC SAZU, Titov trg 2, 6230 Postojna, Slovenia, e-mail: sebela@zrc-sazu.si

${ }^{3}$ Geološki Zavod Slovenije, Dimičeva ulica 14, 1000 Ljubljana, Slovenia, e-mail: milos.miler@geo-zs.si

Received/Prejeto: 11.10.2010
} 


\section{INTRODUCTION}

Black colouring of speleothems could be due to natural or anthropogenic reasons. Among natural sources the most common are: iron and manganese minerals (Onac et al. 1997; Ljubojević et al. 2001; Lopez-Gonzalez et al. 2006), apatite-group minerals derived from bat guano (Hill 1982), soil humic substances derived from overlying soils (White 1997; Van Beynen et al. 2001; Perumplavil \& Armitage 2007), and biogenic origin related to microbial melanin (Saiz-Jimenez 1995). In human inhabited (past and recent) environments black deposits in the form of soot, tar, etc. (Hill 1982) on the surface of building stones and in caves have been considered a result of biomass burning, cooking and fossil fuel combustion (Sabbioni 1995; Saiz-Jimenez 1995; Saiz-Jimenez \& Hermosin 1999; Jeong et al. 2003; Bonazza et al. 2005; Chang et al. 2008).

Out of 9,600 registered caves in Slovenia (Kataster jam IZRK ZRC SAZU) six hold the name Črna, meaning black; and for only two of them we can say that the name comes from the black coating (Tab. 1). The first one is Črna Jama, which is part of Postojna cave system and the second one is the almost $260 \mathrm{~m}$ long horizontal Črna Jama in southern Slovenia (cave register number 2934) where black coating is visible on walls and ceiling. A big stalagmite called Jezni Mož in the most remote chamber is also covered with black coating.

Tab. 1: Caves with black coatings in Slovenia (Kataster jam IZRK ZRC SAZU).

\begin{tabular}{|l|l|l|}
\hline $\begin{array}{l}\text { Cave } \\
\text { register } \\
\text { number }\end{array}$ & Cave & Description of black coating \\
\hline 162 & Črna jama pri Zagorici & no data about black cover \\
\hline 471 & $\begin{array}{l}\text { Črna jama } \\
\text { (Postojna cave system) }\end{array}$ & $\begin{array}{l}\text { black cover on walls, floor, flowstone and collapse } \\
\text { blocks }\end{array}$ \\
\hline 2741 & Črna jama & no data about black cover \\
\hline 2934 & Črna jama & black cover on walls, ceiling and flowstone \\
\hline 3484 & Črna jama & no data about black cover \\
\hline 7924 & Črna špranja & no data about black cover \\
\hline
\end{tabular}

On the other hand, Črna Dvorana (black chamber) is known from Predjama and Črni Rov (black passage) from Kostanjeviška Jama. Black coatings in Slovene caves are described from Kamniška Jama (Urbanc 1982), Najdena Jama (Kashima 1983), Križna Jama 2 (Drole personal communication 2009), underground Pivka channel in Postojna cave system (Gabrovšek personal communication 2009), and from other caves.

Black coatings that cover the cave walls and stones on the floor in Kamniška Jama are mostly very thin, but can reach a thickness of $5 \mathrm{~mm}$. The X-ray diffraction method showed that these black coatings represent $\mathrm{Fe}$ mineral goethite and $\mathrm{Mn}$ minerals pyrolusite and romanèchite (Urbanc 1982).

In Najdena Jama the black to dark brown fine earthy substances occur as a thin soft crust (about $5 \mathrm{~mm}$ thick) covering the cave walls and as fillings in the open-joints of dolomites. By X-ray diffraction method manganite, pyrolusite, todorokite and goethite were detected in that cave (Kashima 1983).

Manganese ions are introduced into caves by stream water and, less frequently, by dripping water or associated with ore mineralization. The soluble $\mathrm{Mn}^{2+}$ in water is oxidized to the insoluble $\mathrm{Mn}^{4+}$, thus causing the precipitation of manganese oxide minerals, a process probably aided by bacteria. Manganese minerals, such as birnessite, usually occur as black layers coating stream cobbles (Hill \& Forti 2004). According to some authors (Moore \& Nicholas 1964; Northup \& Lavoie 2001) microorganisms (for example, bacterium Clonothrix putealis) probably play a part in the origin of the black manganese deposits (birnessite and psilomelane) in caves. In two caves of Eastern Serbia it has been noted that cave passages with black birnessite coatings have a distinct morphology, being highly weathered. Nevertheless, no link between Mn coatings and morphology was established (Ljubojević et al. 2001).

Manganese oxides appear to act as a dosimeter and as indicator of $\mathrm{pH} / \mathrm{Eh}$ fluctuations in water column for heavy metals in karst waters (White et al. 2009).

The entrance parts of the Postojna cave system are known for their black coatings (Fig. 1, site 1). This black colouring relates to a Second World War (WW2). Between $23^{\text {rd }}$ and $24^{\text {th }}$ April 1944, a group of partisans organized an explosion of aviation fuel tanks that were stored in this section of the system. A thunderous noise and big cloud of black smoke was coming out from the main entrance of the cave. The fuel burned for seven days (Fatur 1975). However the black colouring had already been described in 1939-40 (Politi) in these entrance parts. This means that the black colouring existed before 1944 explosion, which might darken the already existing black colouring.

Black coatings on the floor and flowstones gave the name to Črna Jama (Fig. 1, site 2) in Postojna cave sys- 


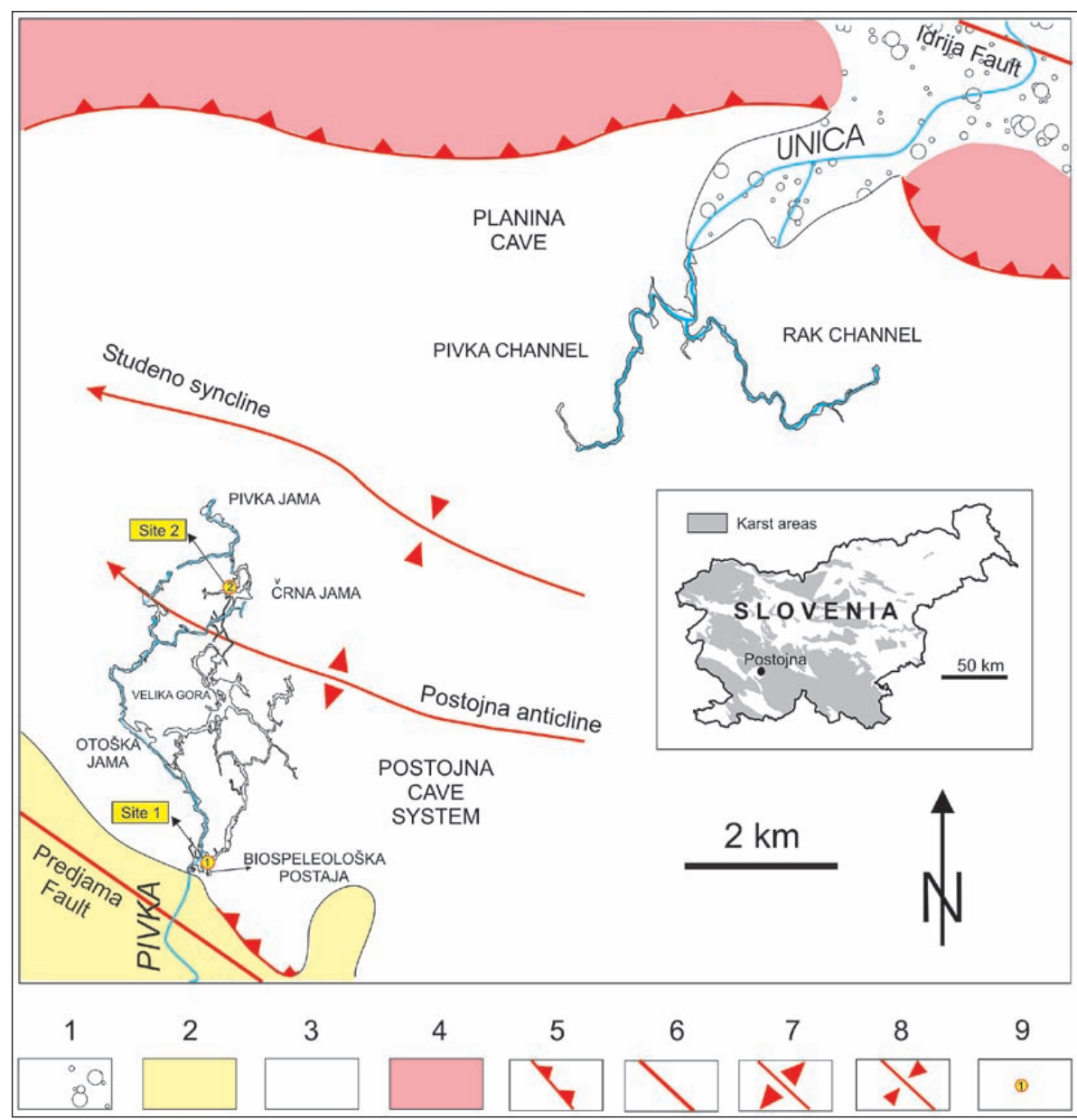

tem. There are several possibilities for the origin of these black coatings: soot deposited by flaming torches, man-
Fig. 1: Basic geology of Postojna and Planina cave systems and sampling points. 1-alluvium (Holocene), 2-flysch (Eocene), 3-limestone (Creatceous), 4-dolomite (Upper Triassic), 5-thrust, 6-fault, 7-anticline, 8-syncline, 9-sampling site of black coatings (1-entrance parts of Postojna cave system, 2-Črna Jama).

ganese compounds, which is deposited by percolating water along with carbonates or maybe prehistoric fires. On the iron railing, a white flowstone up to $5 \mathrm{~cm}$ in thickness was precipitated since 1925 (Habe 1986), which proves that recently deposited flowstone is not black. Although the cave has a natural entrance to the surface, no archaeological remains are documented from Črna Jama.

The aim of this paper is to establish and compare the composition and origin of black coatings from the entrance parts of Postojnska Jama and from Črna Jama.

\section{SITE DESCRIPTION}

The Postojna cave system has $20,570 \mathrm{~m}$ of known passages and is the longest cave in Slovenia. The cave is developed in Upper Cretaceous limestones with typical geological structures (Šebela 1998) known for External Dinarides. Limestone beds are folded and thrusted over Eocene flysch. Cave passages are situated between Idrija Fault (NW-SE) on the north and Predjama Fault (NW-SE) on the south (Fig. 1) and follow bedding-plane direction and dip direction, interbedded slips, fissured zones and Dinaric (NW-SE) and cross-Dinaric (NESW) faults. The Pivka River (Fig. 1) sinks at the contact between Eocene flysch and Upper Cretaceous limestones and flows underground into the Planina Cave.

Taking into account the black coating on cave walls, it has to be mentioned that the oldest part of Postojna town was destroyed by numerous fires. In the last great fire, in 1802 , nearly all the old quarter was burnt down (Habe 1986).

In the travelogue »Walking to Syracuse« by the writer and professor J.G. Seume (1763-1810, written in German), he mentions that at that time the known sections of the Postojna Caves were illuminated by torches carried by guides. Also they used to bring sheaves of straw into the cave which they set alight by the walls of Veliki Dom. From 1830 onwards the cave was illuminated by oil lamps. In 1884 arc-lamps (electric) were installed in the cave (Habe 1986).

Politi (1939-40) described black colouring of the Postojna cave system in parts where cave passages are close to surface accesses, such as entrance parts of the 
cave and Črna Jama. The origin of the colouring was attributed to smoke, to dust originating from outside the cave and also to illumination used during the last century. Regarding Politi's (1939-40) description black colouring in the entrance parts of Postojna cave system was already known before the explosion of aviation fuel in 1944.

Politi (1939-40) stated that in Črna Jama microorganisms are responsible for black coatings. Black surfaces of carbonate flowstone are places of microbic activity. Microorganisms get nutrients from percolating waters from the surface to the cave. Politi (1939-40) suggested

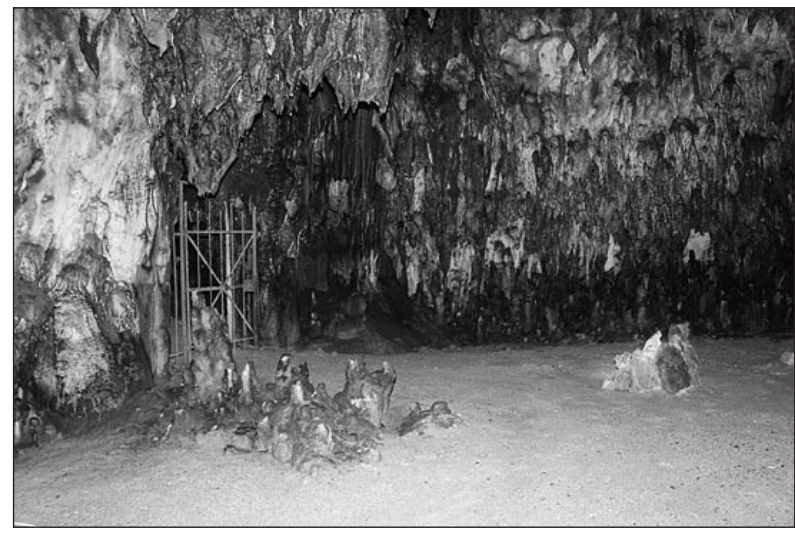

Fig. 2: Black coatings at the entrance to Biospeleološka Postaja, Postojna cave system entrance parts (Photo: S. Šebela).

that different microbic forms developed symbiosis and could also produce melanin substances rather than fixation to $\mathrm{Fe}$ and $\mathrm{Mn}$ oxides.

The explication of the origin of black coatings can be related also to historical aspects of visits in the cave. J.G. Keyssler visited to "St. Mary Magdalene's cave« (Črna Jama) between $2^{\text {nd }}$ and $5^{\text {th }}$ June 1730 . He described that the torches are always lighted to conduct travellers and that the pillars in the cave are as white as snow, and have a kind of transparent lustre not unlike that of white sugar-candy (Shaw 2010, 126). Joseph Anton Nagel vis- ited Črna Jama (Czerna Jama) in 1748 and described many stalactite formations in columns and other shapes, some of them white and other darker (Shaw 2010, 128).

Until 1957 petrol engines were used in the cave. Exhaust gases caused strong smell and soot was deposited on flowstone formations. There was a violent noise and low visibility in the cave (Borjančič 1992).

For mineralogical and chemical analyses of black coatings, two sites in the Postojna cave system were studied (Fig. 1). The first site is the entrance parts to the cave system where black coatings extend to the area of Biospeleološka Postaja (Fig. 2). Black coatings cover

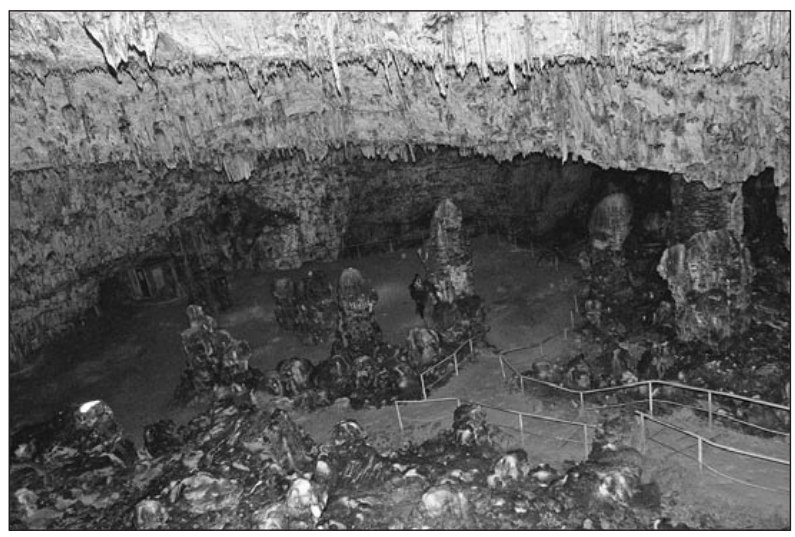

Fig. 3: Black coatings in Črna Jama (Photo: S. Šebela).

flowstones, as well as the cave ceiling and collapse blocks. Scattered samples were taken from an area of about 20 $\mathrm{m}^{2}$ big near Biospeleološka Postaja and $120 \mathrm{~m}$ from the cave entrance.

The second site is Črna Jama (Figs. $1 \& 3$ ). The cave has its natural entrance to the surface. The black coatings in Črna Jama gave the name to this cave and can be found on flowstones, and collapse blocks, and less frequent on the cave ceiling. Samples were randomly collected from an area of about $30 \mathrm{~m}^{2}$ in the western part of Črna Jama and $70-100 \mathrm{~m}$ from the closest cave entrance.

\section{METHODOLOGY}

Black coatings were scraped from the surface of collapse blocks or flowstone near entrance part of Postojna cave system (Fig. 1, site 1), where their main origin is supposed to be due to fuel explosion during WW2, as well as from the part called Črna Jama (Fig. 1, site 2), where their origin is not yet known. We tried to sample as much thin "pure « layer of coatings as possible, but we could not evade the carbonate material. To examine the in depth distribution of the coatings we sampled also flowstones from both locations.

Mineralogical composition and texture of the material were examined in thin sections of scraped mate- 
rial and flowstone, then with the use of X-ray diffraction (XRD) technique and finally by means of scanning electron microscope coupled with energy dispersive X-ray spectrometer (SEM/EDS), which enabled qualitative and at least partial semi-quantitative control of chemical composition. Samples from both locations were also fired at 350,700 and $1000{ }^{\circ} \mathrm{C}$ to establish its organic composition.

Powder X-ray diffraction measurements were conducted in the Department of Geology at the Faculty of Natural Sciences in Ljubljana using a Philips PW 3830/40 diffractometer, equipped with $\mathrm{CuKa}$ radiation. The X-ray radiation was generated with a tension of 40 $\mathrm{kV}$ and a current of $30 \mathrm{~mA}$ and was filtered with a graphite monochromator. Data were recorded in the range $2^{\circ}$ $\leq 2 \Theta \leq 70^{\circ}$. For mineralogical analysis 2 samples were prepared, one from each location marked on Fig. 1.

SEM/EDS analysis was carried out in low vacuum mode using a scanning electron microscope JEOL JSM $6490 \mathrm{LV}$, coupled with an energy dispersive spectrom- eter Oxford INCA Energy at accelerating voltage $20 \mathrm{kV}$ and working distance $10 \mathrm{~mm}$. Uncoated samples were observed in BSE (backscattered electron) mode, which allows identification of particles by relative elemental composition (atomic number). Qualitative chemical composition of particles was measured using EDS point $\mathrm{X}$-ray microanalysis with acquisition time $10 \mathrm{~s}$ to $30 \mathrm{~s}$. Semi-quantitative results provided an estimate of relative differences in contents of elements from different analyzed areas. X-ray spectra were optimized for quantification using Co optimization standard and the correction of EDS data was performed on basis of the standard ZAF-correction procedure included in the INCA Energy software. Quantification of elements in the low vacuum SEM/EDS analysis is generally unreliable, however, relative proportions between constituent elements in individual particles could be assessed. All scanning electron microscopy and energy dispersive spectrometry investigations were performed in the laboratory at Geological Survey of Slovenia.

\section{RESULTS AND DISCUSSION}

Microscopic investigation of thin sections of scraped material from both locations revealed that the main material is carbonate (calcite), with evenly dispersed prevailingly minute opaque black grains. The size of these grains is not larger than $40 \mu \mathrm{m}$. Black grains rarely appear as rim surrounding single calcite grains. The same holds true for the flowstone samples, except that sometimes there are layers of higher concentration of black grains, showing concentric growth (Fig. 4). Individual layer is $40 \mu \mathrm{m}$ thick, whereas the whole rim is up to $400 \mu \mathrm{m}$. Their thickness is comparable to those black layers attributed to urban aerosols from South Korean tourist caves (Chang et al. 2007), where pollutants are concentrated at the surface of the speleothems, and 0.1 to several millimetres thick and, more important, to laminae interpreted as result of combustion of plant material within several caves (Gradziński et al. 2007).

Under cross-polarized light flowstone thin sections show fibro-radial growth of calcite crystals (Fig. 4). Between them there are some pores filled with fine grained material. We noticed black spheres (120 to $150 \mu \mathrm{m})$ of which origin is not clear; they may represent contamination introduced during thin section preparation. Under polarized microscope it was not possible to identify either the mineral composition of this fine material or that of black opaque grains.

In spite of the fact that by scraping the surface we tried to sample concentrated black material, XRD pat- terns (Fig. 5) of samples from both locations, confirmed just the presence of calcite with minor quartz and dolomite. However the result is important because excludes $\mathrm{Mn}$ and $\mathrm{Fe}$ oxides or phosphates as an explanation for

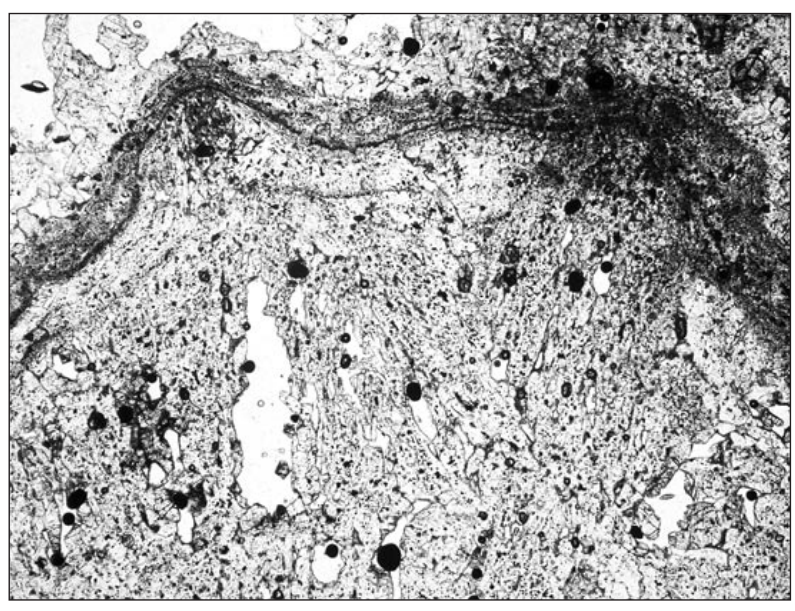

Fig. 4: Črna Jama: elongated radiating calcite crystals with black inclusions and concentric belts of fine black material (plane light). Length of the picture is $5 \mathrm{~mm}$.

black colouring. Still we cannot rule them out completely as the method is not able to detect amorphous or micro-grained matter as well as minerals present in 
less than $2-3 \%$. But in the majority of cases where black coatings in the caves were identified as $\mathrm{Mn}$ and/or Fe oxides, their presence was clearly confirmed by XRD and the layers are also generally much thicker (Urbanc 1982; Kashima 1983; Onac et al. 1997; Ljubojević et al. 2001).

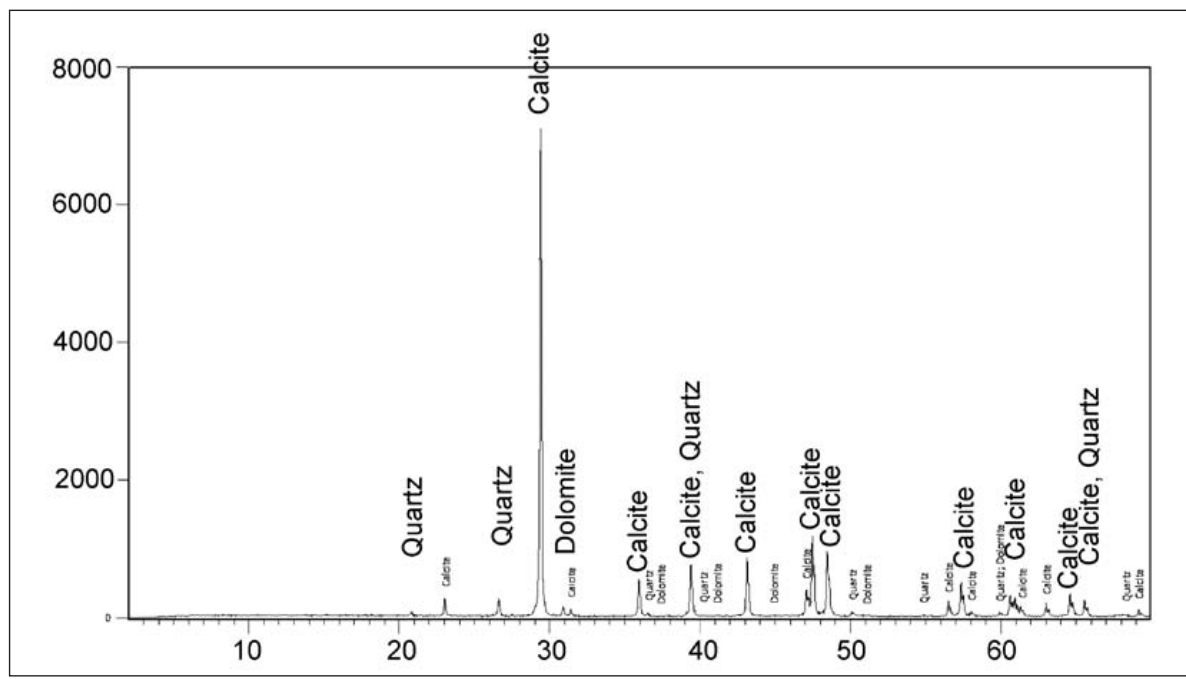

Fig. 5: Črna Jama: XRD pattern showing predominant calcite with minor dolomite and Quartz. $x-2 \theta, y$ axis - peak intensity (cps).

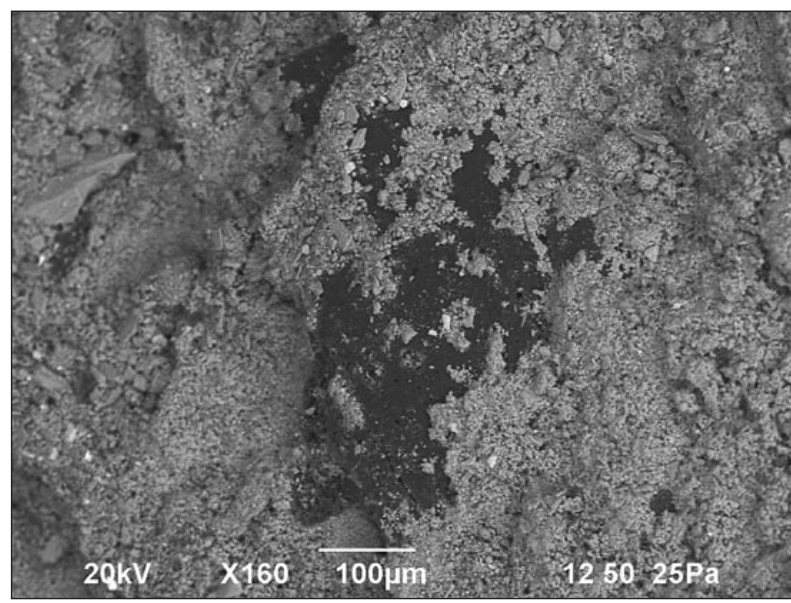

Fig. 6: Entrance parts of Postojna cave system. Rough grained surface with some idiomorphic crystals, bright spheres and black coating.

SEM analysis of scraped material and flowstone samples from entrance parts of Postojna cave system (Fig. 6) shows that the surface of the samples is very rough grained with some idiomorphic crystals, bright spheres and dark coating.

Elementary composition was ascertained from SEM/EDS spectrum measured at certain points (Fig. 7). The greater part of greyish xenomorphic grains corresponds to calcium carbonate as confirmed with measure- ment in spectrum 4 . The XRD analysis and thin section inspection indicate calcite. Other elements in the spectrum $4(\mathrm{Si}, \mathrm{Al}, \mathrm{K}, \mathrm{Fe}, \mathrm{Mg})$, established in very low concentrations, most probably originate from fine-grained clay minerals that occur in the surroundings of calcite grains. Some idiomorphic grains are not carbonate as expected from the crystal form, but clay minerals (spectrum 2). Most of the detrital minerals are likely derived from soil (Jeong et al. 2003).

In places we noticed increased content of iron (bright grains - spectrum 5, Fig. 7), which could be interpreted as $\mathrm{Fe}$ oxides. But such grains are so rare, that could not be a reason for the black colour of the coatings. Interesting features are some bright spheres with very high metal ( $\mathrm{Fe}, \mathrm{Cr}, \mathrm{Ni})$ content (Spectrum 3). These spherical particles typically form during the melting of steel at high temperatures (Aragon et al. 2000; Tasić et al. 2006), followed by rapid cooling in the air. They could originate from the metal parts molten at the time of petrol explosion, or from later period due to sparkling and wearing out of railway tracks used by tourist train in the Postojna cave system (Borjančič 1992). Only in this type of material some Mn was detected, but the content is way too small to contribute to black colour of sediment. The result is in consistence with XRD analysis, which did not show any Mn oxides.

Evidently contrasting is high content of $\mathrm{C}$ measured in the black coating and represented in spectrum 1. Lack of a significant amount of any other element (except $\mathrm{O}$ and some $\mathrm{Ca}$ ) indicates relatively pure carbon, which deposited on the cave walls at time of petrol explosion during WW2. We tried to establish the form of carbon by firing the samples for 2 hours at 350,700 and $1000{ }^{\circ} \mathrm{C}$. The sample changed the colour from black to light grey only after firing at highest temperature, which indicates more complex carbon compounds, similar to the one found as a consequence of fuel exhaust. But we were not able to recognize chain-like agglomerates (ca. 0.2-1.1 $\mu \mathrm{m}$ diameter) of sub-micrometer carbon spheres (ca. 0.02-0.05 $\mu \mathrm{m}$ diameter) which are considered to originate mostly from automobile exhaust as in some tourist caves in Korea (Jeong et al. 2003).

In the case of Črna Jama SEM/EDS pictures are completely different, showing typical structures of drip- 

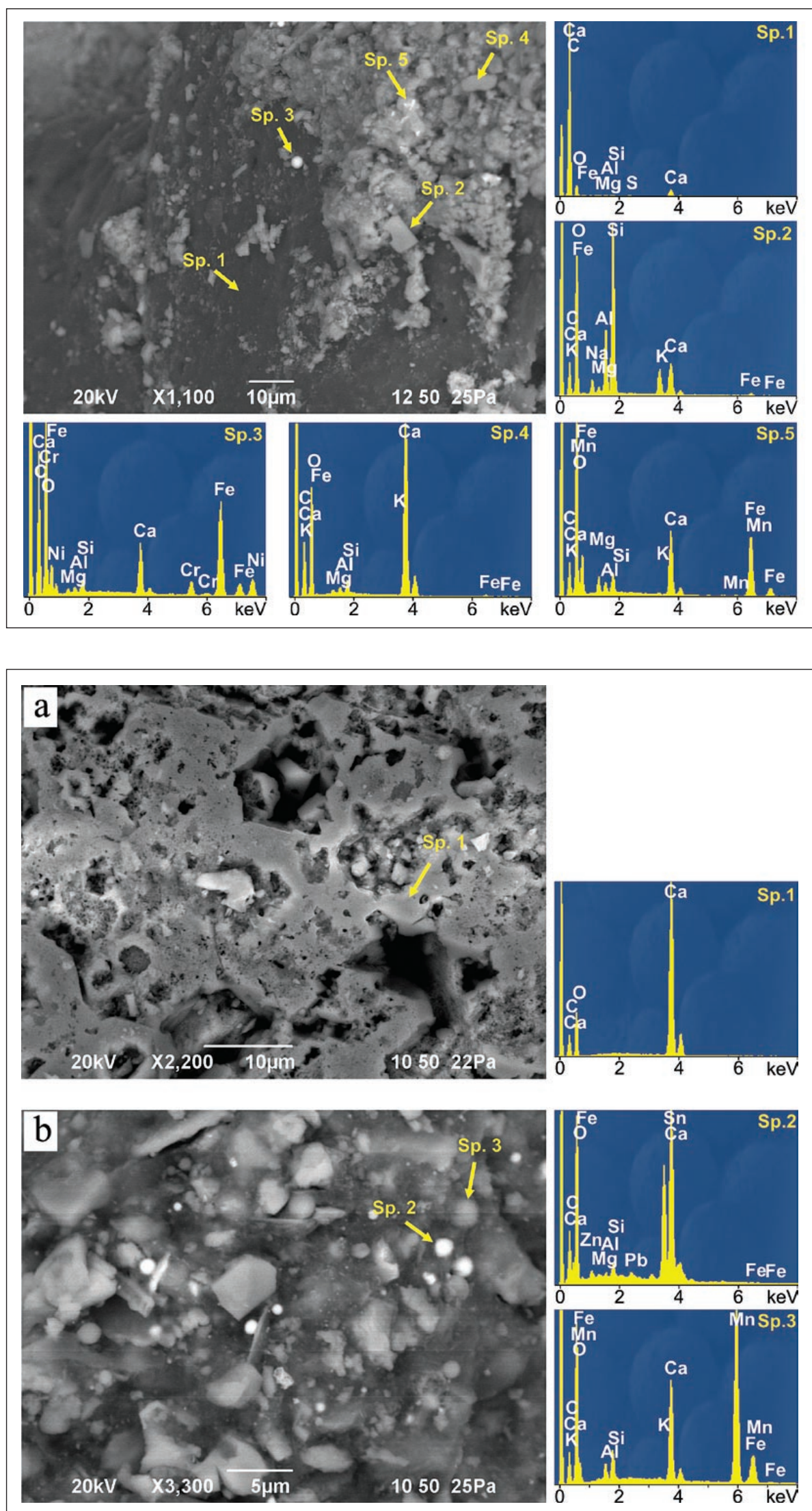

Fig. 7: Postojna cave system entrance parts. SEM/EDS analysis showed dark coating with elevated carbon content (spectrum 1 - Sp. 1); clay mineral grain (spectrum 2 - Sp. 2); metallic sphere containing $\mathrm{Fe}, \mathrm{Cr}$ and $\mathrm{Ni}$ (spectrum 3 - Sp. 3); carbonate (spectrum 4 - Sp. 4); and particles with increased $\mathrm{Mn} / \mathrm{Fe}$ content (spectrum 5 - Sp. 5).

stone (Fig. 8a) - smooth surface with pores. Chemically material corresponds to pure calcium carbonate, as seen from the spectrum 1 .

Some pores are filled with fine-grained material of the same calcite composition or clay minerals and, surprisingly, sometimes very small bright spheres were observed (Fig. 8b). Their EDS spectra show presence of $\mathrm{Fe}$ and/or Mn (spectrum 3), in one case even $\mathrm{Sn}, \mathrm{Pb}$ and $\mathrm{Zn}$ (spectrum 2). Onac et al. (1997) report on iron reach spheres with high REE content found in ferromanganese coatings, which formed after being leached from bauxite and residual clays from above the cave. In our case the origin of this material is doubtful, but it might be an urban and industrial emission of combustion sources (Fernandes et al. 2003; Maravelaki-Kalaitzaki 2005; Chang et al. 2007).

Fig. 8: Črna Jama: a) Smooth calcite drip-stone surface with pores. Spectrum 1 (Sp. 1) shows composition of pure calcium carbonate; b) Pores filled with fine-grained material of calcitic composition or clay minerals and, surprising$l y$, sometimes very small bright spheres containing $\mathrm{Fe}$ and/or $\mathrm{Mn}$ (spectrum 3 - Sp. 3) and $\mathrm{Sn}, \mathrm{Pb}$ and $\mathrm{Zn}$ (spectrum 2 - Sp. 2) were observed. 
Under the SEM, black coatings in Črna Jama were scarcer, and their form appears different from coatings found in entrance parts of Postojna cave system. In some cases (Fig. 9a) they resemble wood charcoal or vegetation fire residues (Fernandes et al. 2003). However, in the spectrum 1 there is no evidence for extreme enrichment with carbon - at least not to the same degree as in the case of the entrance parts of Postojna cave system. Similar coatings found in some Polish caves are interpreted as wood combustion caused by prehistoric human activity. The ultra structures of charcoal particles prove that most originated in temperatures ranging from 400 up to $600{ }^{\circ} \mathrm{C}$, suggesting that charcoal is connected with domestic fires rather than torches (Gradziński et al. 2003). The occurrence of laminae within flowstones close to the cave entrance shows that components of tracing dyes could be transported into the cave by wind action (Gradziński et al. 2007). As in Črna Jama no other evidence indicates human inhabitation of the place, charcoal occurrence could not be unambiguously explained.

Interesting is the occurrence of a small dark coloured needle nest (Fig. 9b). We measured its chemi-
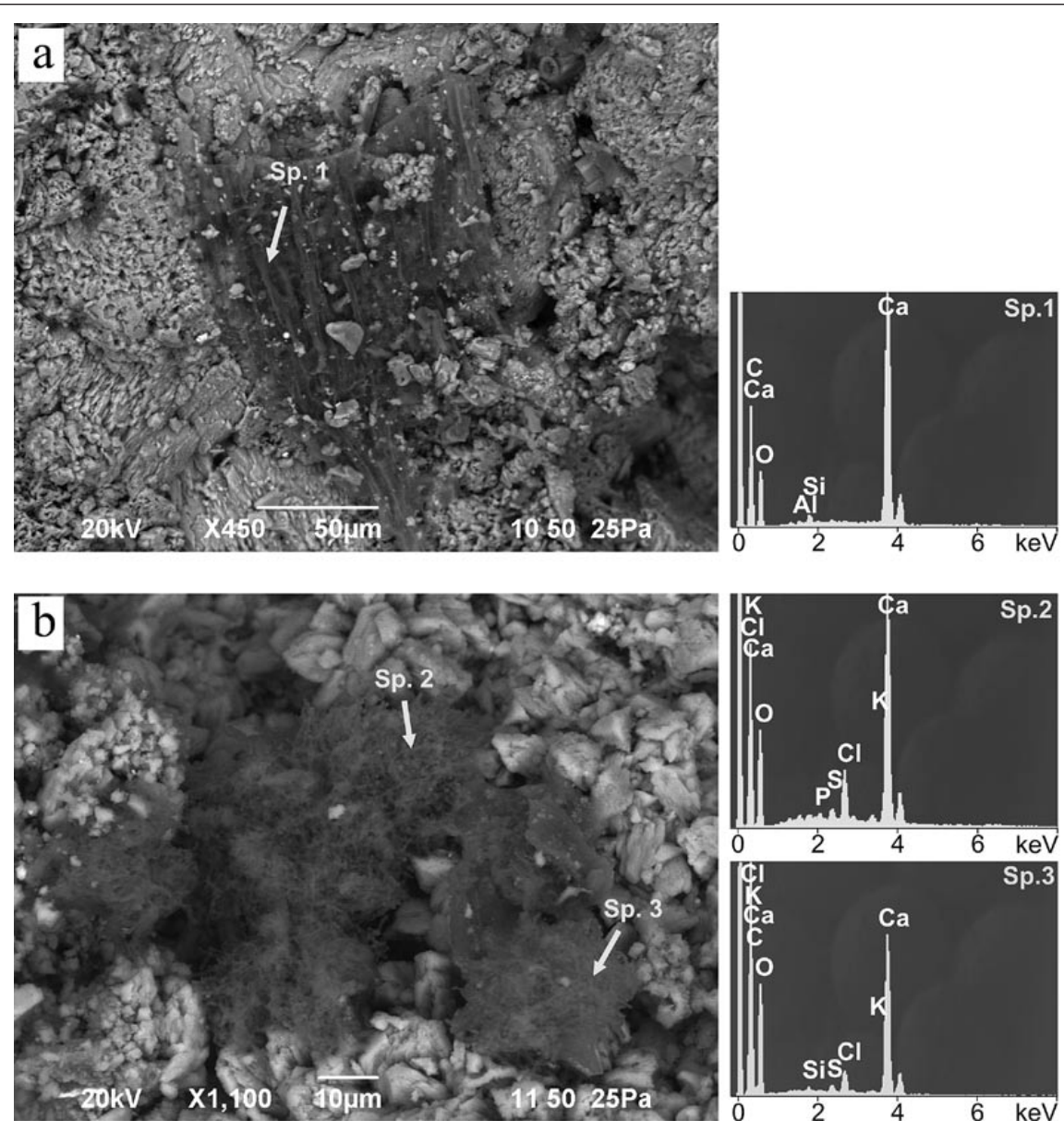

cal composition at two points (spectra 2, 3) and, besides usual $\mathrm{O}, \mathrm{C}, \mathrm{Ca}, \mathrm{Si}$ and $\mathrm{K}$, ascertained presence of $\mathrm{P}, \mathrm{S}$ and $\mathrm{Cl}$ as well. Some authors explain such forms as microorganism or guano, which is easily distinguished from black carbon by its high phosphorus content (Jeong et al. 2003), but there is no evidence besides $\mathrm{P}$ content to prove it. Chlorides and phosphates were also detected in smaller and variable quantities in black crust on different urban buildings (Bonazza et al. 2005). Those origins may explain local phenomena in some caves, but not the extensive colouration (Jeong et al. 2003).

We can attribute black coatings from Črna Jama to one form of organic carbon, which is certainly different from the one in the entrance parts of Postojna cave system. According to Bonazza et al. (2005) the quantification of carbon in black crusts represents a complex problem, as it is composed of different fractions. But for a rough confirmation of the existence of organic carbons (OCs) and black carbon (BC), heating of samples at 350, 700 , and $1000{ }^{\circ} \mathrm{C}$ for 2 hours at each single heating step gives some information (Chang et al. 2007).

When firing the sample from Črna Jama, at $350^{\circ} \mathrm{C}$ it did not change colour, but at $700{ }^{\circ} \mathrm{C}$ turned light grey and at $1000^{\circ} \mathrm{C}$ white. The colour change above the temperature of $700{ }^{\circ} \mathrm{C}$ suggests that the black pigments are not low molecular OC, which is oxidized at $350{ }^{\circ} \mathrm{C}$, but are high molecular OC and/or BC (Chang et al. 2007). Potential constituents of the OC are: (1) an anthropogenic combustion organic product adsorbed onto the BC (Flagan \& Seinfeld 1988); (2) microorganisms; (3) biological weathering products such as humic acid, fulvic acid and particulate organic matter (Ghedini et al. 2000).

Fig. 9: Črna Jama: a) Black coating resembling wood charcoal or vegetation fire residues (spectrum 1 - Sp. 1); b) Small dark coloured needle nest with $\mathrm{P}, \mathrm{S}$ and $\mathrm{Cl}$ in EDS spectra 2, 3 (Sp. 2, 3). 
Opposite to Chang et al. (2007) we have not measured practically no sulphates and nitrates, typical tracers of industrial and urban emissions.

The thin black outer zone from both locations suggests that the black colouring of speleothems has begun recently. Considering known growth rates of natural spe- leothems, averaging a few tenths of a millimetre per year (Moore \& Sullivan 1997), the period of BC pollution is several decades old. The possible internal sources of $\mathrm{BC}$ are biomass burning from torch and candle emission and fossil-fuel combustion from oil lamp and so forth that occupants may have introduced.

\section{CONCLUSIONS}

Scattered samples of black coatings were taken from entrance parts of Postojna cave system and from Črna Jama (Fig 1). The XRD from both locations confirmed the presence of calcite with minor quartz and dolomite, excluding $\mathrm{Mn}$ and $\mathrm{Fe}$ oxides or apatite-group minerals (bat guano) as the cause for black colouring. The SEM/EDS analysis of samples from the entrance parts of Postojna cave system did not show any Mn oxides as well. High content of $\mathrm{C}$ and change of colour only after burning the material at $1000{ }^{\circ} \mathrm{C}$ may document for organic $\mathrm{C}$, which deposited on the cave walls at time of the aviation fuel explosion during WW2. This colouration could cover the black colour resulting from earlier use of torches in the cave. Higher content of Fe accompanied with increased concentration of $\mathrm{Cr}$ and $\mathrm{Ni}$ was observed in some bright spheres. They could originate from the metal parts molten at the time of petrol explosion, or from later period due to sparking and wearing out of railway tracks used by tourist train in the Postojna cave system.

In the case of Črna Jama thin section and XRD analysis gave the same results as for samples from the entrance part of Postojna cave. But under the SEM/EDS dark coloured areas were scarcer. Nevertheless the overall carbon content was too high to be attributed just to carbonate, but lower as measured in first location. The EDS spectrum showed presence of Fe and/or Mn, and in one case even $\mathrm{Sn}, \mathrm{Pb}$ and $\mathrm{Zn}$ only in small bright spheres. The origin of this material is questionable, but it might be an urban and industrial emission of combustion sources. We can attribute black coatings from Črna Jama to one form of organic carbon, which is certainly different from entrance parts of Postojna cave system. The torches used by guides and cave visitors during centuries are the probable origin of charcoal in Črna Jama. On both locations black coatings can be at least partly described by microclimate conditions at cave entrances, which caused the deposition of organic material of outer origin (for example soot due to the forest fires).

Could higher number of tourists in the Črna Jama after 1730 significantly add to the black coatings? We believe that further investigations need to be done, as dating of carbon, but that is already a new discussion.

\section{ACKNOWLEDGMENTS}

The idea for this article came out from conversation with the late Mr. Bogdan Debevc (1956-2009). In his memory we started with analyses of black coatings from Črna Jama. We are thankful to Postojnska jama, d.d., for realization of this idea and to geology student Rok Brajkovič for laboratory preparation of samples. Trevor Shaw sig- nificantly improved the original manuscript. The study was performed within the Karst Research Programme (P6-0119) and Measurements and Analysis of Selected Climatic Parameters in Karst Caves: Example of the Postojna Cave System (L6-2156). 


\section{REFERENCES}

Aragon, A.P., Torres, G.V., Monroy, M.F, Luszczewski, A.K. \& R.R. Leyva, 2000: Scanning electron microscope and statistical analysis of suspended heavy metal particles in San Luis Potosi, Mexico.- Atmospheric Environment, 34, 4103-4112.

Bonazza, A., Sabbioni, C. \& N. Ghedini, 2005: Quantitative data on carbon fractions in interpretation of black crusts and soiling on European built heritage.Atmospheric Environment, 39, 14, 2607-2618.

Borjančič, A., 1992: 120 let železnice v Postojnski jami 1872-1992.- Notranjski kompleksni muzej, pp. 41, Postojna.

Chang S.J., Jeong, G.Y. \& S.J. Kim, 2008: The origin of black carbon on speleothems in tourist caves in South Korea: Chemical characterization and source discrimination by radiocarbon measurement.- Atmospheric Environment, 42, 8, 1790-1800.

Fatur, S. 1975: Partizanska akcija v Postojnski jami.- In: Fatur S. (ed.) Ljudje in kraji ob Pivki. Kulturna skupnost Postojna, 298-301, Postojna.

Fernandes, M.B., Skjemstad, J.O., Johnson, B.B., Wells, J.D. \& P. Brooks, 2003: Characterization of carbonaceous combustion residues. I. Morphological, elemental and spectroscopic features.- Chemosphere, 51, 8, 785-795.

Fezzey, S. \& R.A. Armitage, 2006: Pyrolysis GC-MS and THM-GC-MS studies of a black coating from Little Lost River Cave, Idaho.- J. Anal. Appl. Pyrolysis, 77, 2, 102-110.

Flagan, R.C., \& J.H. Seinfeld, 1988: Fundamentals of air pollution engineering.- Prentice Hall, pp. 542, Englewood Cliffs, New Jersey.

Ghedini, N., Gobbi, G., Sabbioni, C. \& G. Zappia, 2000: Determination of elemental and organic carbon on damaged stone monuments.- Atmospheric Environment, 34, 4383-4391.

Gradziński M., Górny A, Pazdur A. \& M.F. Pazdur, 2003: Origin of black coloured laminae in speleothems from the Kraków-Wieluń Upland, Poland.- Boreas, 32, 3, 532-542.

Gradziński, M., Hercman, H., Nowak, M. \& P. Bella, 2007: Age of black coloured laminae within speleothems from Domica cave and its significance for dating of prehistoric Human settlement.- Geochronometria, 28, 39-45.

Habe, F., 1986: The Postojna caves and other Tourist Caves in Slovenia.- Tone Tomšič Printing House, pp. 82, Postojna.
Hill, C.A. \& P. Forti, 1997: Cave Minerals of the World (second edition).- National Speleological Society, pp. 463, Huntsville, Alabama, USA.

Hill, C.A., 1982: Origin of black deposits in caves.- National Speleological Society Bulletin, 44, 15-19.

Hill, C.A. \& P. Forti, 2004: Minerals in caves.- In: Gunn J. (ed.) Encyclopedia of Caves and Karst Science. Fitzroy Dearborn, 511-514, New York, London.

Jeong, G.Y., Kim, S.J. \& S.J. Chang, 2003: Black carbon pollution of speleothems by fine urban aerosols in tourist caves.- American Mineralogist, 88, 1872 1878.

Kashima, N., 1983: On the Wad-Minerals from the Cavern Environment.- International Journal of Speleology, 13, 67-72.

Kataster jam IZRK ZRC SAZU, Postojna.

Ljubojević, V., Pacevski, A., \& J. Ćalić-Ljubojević, 2001: On the genetic conditions of black manganese deposits from two caves of Eastern Serbia.- Theoretical and Applied Karstology, 13-14, 75-79.

Lopez-Gonzalez, F., Grandal-d’Anglade, A. \& J.R. VidalRomani, 2006: Deciphering bone depositional sequences in caves through the study of manganese coatings.- Journal of Archaeological Science, 33, 707-717.

Maravelaki-Kalaitzaki, P., 2005: Black crusts and patinas on Pentelic marble from the Parthenon and Erechtheum (Acropolis, Athens): characterization and origin.- Analytica Chimica Acta, 532, 2, 187-198.

Moore, G.W., 1981: Manganese Deposition in Limestone Caves.- In: Beck, B.F. (ed.) Proceedings of the eight international congress of speleology, 18-24 $4^{\text {th }}$ July 1981, Volumes I and 2, Bowling Green, Kentucky. International Union of Speleology, 642-644, Bowling Green.

Moore, G.W. \& B.G. Nicholas, 1964: Speleology.D.C.Heath and Company, pp.120, Boston.

Moore, G.W. \& N. Sullivan, 1997: Speleology.- Cave books, pp. 176, St. Louis.

Northup, D.E. \& K.H. Lavoie, 2001: Geomicrobiology of Caves: A Review.- Geomicrobiology Journal, 18, 3, 199-222.

Onac, B.P., Pedersen, R. B. \& M. Tysseland, 1997: Presence of rare-earth elements in black ferromanganese coatings from Vântului cave (Romania).- Journal of Cave and Karst Studies, 59, 3, 128-131.

Perumplavil, R. \& R.A. Armitage, 2007: Surface analysis of black deposit from Little Lost River Cave, Idaho.A.C.S. symposium series, 968, 152-166. 
Politi, I., 1939-40: Sui fenomeni di annerimento delle formazioni calcitiche e calcaree nelle Grotte di Postumia.- Le Grotte d'Italia, 2a, IV, 18-23.

Sabbioni, C., 1995: Contribution of atmospheric deposition to the formation of damage layers.- The Science of the Total Environment, 167, 49-55.

Saiz-Jimenez, C., 1995: Reactivity of the aliphatic humic moiety in analytical pyrolysis.- Organic Geochemistry, 23, 10, 955-961.

Saiz-Jimenez, C. \& B. Hermosin, 1999: Thermally assisted hydrolysis and methylation of the black deposit coating the ceiling and walls of Cueva del Encajero, Quesada, Spain.- Journal of Analytical and Applied Pyrolysis, 49, 1-2, 349-357.

Shaw, T., 2010: Aspects of the History of Slovene Karst 1545-2008.- Založba ZRC, pp. 306, Ljubljana.

Tasić, M., Đurić-Stanojević, B., Rajšić, S., Mijić, Z. \& V. Novaković, 2006: Physico-Chemical Characterization of PM10 and PM2.5 in the Belgrade Urban Area.- Acta Chimica Slovenica, 53, 401-405.
Šebela, S., 1998: Tectonic structure of Postojnska jama cave system.- Založba ZRC, 18, pp. 112, Ljubljana.

Urbanc, J., 1982: Kamniška jama.- Naše jame, 23-24 (1981/82), 25-34.

Van Beynen, P., Bourbonniere, R., Ford, D., \& H. Schwarcz, 2001: Causes of colour and fluorescence in speleothems.- Chemical Geology, 175, 319-341.

White, W.B., 1997: Color of speleothems.- In: C. Hill \& P. Forti (eds.) Cave Minerals of the World, second edition, 239-244, National Speleological Society, Huntsville.

White, B.W., Vito, C. \& B.E. Scheetz, 2009: The mineralogy and trace elements chemistry of black manganese oxide deposits from caves.- Journal of Cave and Karst Studies, 71, 2, 136-143. 